\title{
The Judgments of the European Court of Human Rights as Sources of Standards of Rights and Freedoms of Man and Citizen in the Russian Federation
}

\author{
Tatiana V. Prikhod'ko* \\ Baikal State University \\ 11 Lenin Str., Irkutsk, 664003, Russia
}

Received 26.04.2017, received in revised form 05.06.2017, accepted 09.06.2017

\begin{abstract}
The article investigates the legal force of the judgments of the European Court of Human Rights in Russia in accordance with the Judgment No. 21-P dated July 14, 2015 of the Constitutional Court of the Russian Federation. It also analyzes the practice of cooperation between the Federal Republic of Germany and the European Court of Human Rights as well as the Court of the European Union, the comparative legal method of research being applied to the analysis. The author comes to a conclusion on positive and negative consequences caused by the departure from the Judgment No. 21-P dated July 14, 2015 of the Constitutional Court of the Russian Federation.
\end{abstract}

Keywords: human rights, freedoms, legal force, sovereignty, right of exception, dialogue of courts, the Constitution of the Russian Federation, the European Convention on Human Rights and Fundamental Freedoms, the European Court of Human Rights, the Constitutional Court of the Russian Federation, Judgment of the Constitutional Court of the Russian Federation on July 14, 2015 No. 21-P, the Federal Republic of Germany, the Basic Law for the Federal Republic of Germany, the Court of Justice of the European Union, the Federal Constitutional Court of Germany.

DOI: 10.17516/1997-1370-0119.

Research area: law.

Basing on the provisions of part 1 of Article 17, Article 18, part 1 of Article 55, the Constitution of the Russian Federation recognizes that rights and freedoms of man and citizen are guaranteed under the generally recognized principles and norms of international law and are directly applicable regardless of their being fixed by the Constitution. According to the Russian legal literature, the sources of standards of rights and freedoms of man and citizen are the Constitution of the Russian Federation, norms of international law, "soft law" (Prikhod'ko, 2013: 117), the judgments of the Constitutional Court of the Russian Federation (this feature results from the obligatory status of its judgements for all the other subjects of law in the Russian Federation), as well as acts of enforcement issued by the international bodies, the European Court of

(C) Siberian Federal University. All rights reserved

* Corresponding author E-mail address: prikhodko_tv@mail.ru 
Human Rights having a special role among then (Zor'kin, 2004: 4).

When ratifying the European Convention for the Protection of Human Rights and Fundamental Freedoms and the protocols thereto, it was stated that the Russian Federation "recognizes ipso facto and without special agreement the binding jurisdiction of the European Court of Human Rights on interpretation and application of the Convention and protocols thereto in cases of alleged violations by the Russian Federation of the provisions of these legal acts when the alleged violations have taken place after their entry in force in relation to the Russian Federation"'. This implies that it is necessary for the state under consideration to execute the judgments of the European Court of Human Rights regarding disputes, the Russian Federation being a party thereof.

In this regard, O.A. Kozhevnikov notes that "we cannot forget that, according to Clause 4 of Article 15 of the Constitution of the Russian Federation, the European Convention for the Protection of Human Rights and Fundamental Freedoms is an integral part of the Russian legal system; thus, the judgments of the European Court must be taken into account by the Federal legislator at regulating social relations and by law-enforcement authorities at applying the relevant rules of law" (Kozhevnikov, 2010: 68).

When making their judgments the courts of the Russian Federation refer to the judiciary law practice of the European Court of Human Rights in respect not only of the Russian Federation but other participant-states of the Convention ${ }^{2}$ as, in compliance with the recommendations of the Committee of Ministers of the Council of Europe, "a necessary condition for effective human rights protection in Europe under the Convention is when the states apply the Convention in their legal systems the way it is understood in the judiciary law practice of the European court"
(Churkina, 2005: 120). It is obvious that proper understanding of the standards proposed by the European Convention is impossible without reference to the practice of the European Court of Human Rights also because of the fact that the interpretation of the provisions of the Convention and protocols thereto by the European Court of Human Rights often leads to the development of a provision expanding the content of existing standards or even shaping a new standard (Tiunov, 2012: 73).

In this regard, A.L. Burkov notes that "the practice of applying the Convention without understanding the actual value of the applicable provisions causes more harm than good and leads to an incorrect adjudication of a case, despite a semblance of positive application of an international document" (Burkov, 2006: 39). In P.A. Laptev's opinion, this is precisely why it is necessary to recognize that "the provisions of the Convention do not exist by themselves, but only in the form in which they are understood and applied by the European Court of Human Rights (Laptev, 2003: 32).

A sort of classification of legal propositions of the European Court of Human Rights and corresponding legal consequences for Russia were outlined in the Decree of the Plenum of the Supreme Court of the Russian Federation No. 21 dated June 27, 2013. In compliance with the Decree, firstly, the legal propositions of the European Court of Human Rights defined in the Court judgments in relation to the Russian Federation are recognized as mandatory for the Russian courts. Secondly, the Russian courts should take into account the legal propositions of the European Court set out in the decisions in relation other participant-states of the Convention and when the circumstances of a case considered by the European Court of Human Rights are similar to the circumstances of a case considered by a court of the Russian Federation. However, 
this provision does not apply if the legislation of the Russian Federation provides for a higher level of protection of the rights and freedoms compared to the Convention ${ }^{3}$.

This perception of practice of the European Court for Human Rights was peculiar for the Russian Federation up to 2015. However, a number of judgments of the European Court of Human Rights regarding the Russian Federation ("Konstantin Markin vs. Russia", "Anchugov and Gladkov vs. Russia"5), led to the revision of this proposition by the Constitutional court of the Russian Federation.

The matter is that the feature of obligation of the judgments of the European Court of Human Rights for domestic legal systems is closely related to such a delicate political issue as state sovereignty. The European Convention for the Protection of Human Rights and Fundamental Freedoms was signed by 47 countries with different legal systems. Thus, the matter that is recognized as the norm by one state can often be in conflict with national, cultural or ethnic peculiar features of another state.

In this regard in Judgment No. 21-P dated 14.07.2015 the Constitutional Court of the Russian Federation stated the necessity for the "dialogue" in the relations of the European Court of Human Rights with the national courts to ensure the necessary balance of values, formed in the course of practice of the European Court of Human Rights, and the elements of a state's national identity. It also pointed to a preferential effect of the Constitution of the Russian Federation in the Russian legal system, the official interpretation of the Constitution relating to the competence of the Constitutional Court of the Russian Federation.

The following fundamental rule was formulated: "If the decree of the European Court of Human Rights, issued on the complaint against Russia, is based on the interpretation of the provisions of the Convention on the protection of human rights and fundamental freedoms, leading to their contradiction with the Constitution of the Russian Federation, this decree <...> cannot be subject to execution" ${ }^{\text {" }}$. In other words, the practice of the European Court on Human Rights matters to the Russian state authorities only insofar as it is not in conflict with the Constitution of the Russian Federation.

The Constitutional Court of the Russian Federation, however, called the reference to this principle ("the right of exception" against the execution of judgments of the European Court of Human Rights) an extraordinary measure, thus recognizing an important role of the European Court of Human Rights in improving national legal system?.

In so doing, the Constitutional Court of the Russian Federation made a clear distinction between the European Convention of Human Rights and Fundamental Freedoms and the practice of the European Court of Human Rights. According to the Constitutional Court of the Russian Federation, these are the provisions of the European Convention of Human Rights and Fundamental Freedoms (as norms of international law) but not the practice of the European Court of Human Rights which are mandatory for the Russian Federation in compliance with Clause 4 of Article 15 of the Constitution of the Russian Federation $^{8}$.

It should be noted that the proposition of the Constitutional Court of the Russian Federation, stated in Judgment No. 21-P dated 14.07.2015, is to some extent based on legal practice of the Federal Constitutional Court of Germany in this field. In this regard it is worth while referring to German legal practice.

It should be noted that since the Federal Republic of Germany is one of the countries of the European Union in this state (the Federal Republic of Germany) the Court of the European Union also exercises its functions of protection of 
fundamental rights and freedoms along with the Federal Constitutional Court and the European Court of Human Rights. In this regard, German scientists in the field of the constitutional system mentioned that the problem of coexistence of courts of different levels should not be confined only to the problem of their hierarchy as it is wrong to give absolute priority to the decisions of the European courts, at the same time questioning the state sovereignty and rejecting the practice of the national courts that was historically formed in the state, basing on its legal culture, political and national peculiar features (Kirchhof, 2011: 3682). At the same time, uncertainty of the actions of "protective barriers" can to some extent slow down the decision-making process regarding the case. Besides, the denial of the role of the European courts negates both the efforts on creating a common European law and observance of human rights standards. Therefore, only the "dialogue" (Kirchhof, 2011: 3682) of courts and their collaboration can solve the intended problems (For more details re. to [Prikhod'ko, 2013: 664). In addition, the need to take into account the scale of actions of a certain court was specified.

The competence of the European Court of Human Rights should be considered first. This Court is empowered to consider complaints on violation of rights and freedoms provided for by the European Convention for the protection of human rights and fundamental freedoms and protocols thereto, that is to ensure the compliance with the minimum standards in the field of rights and freedoms.

In one of its decisions (Fall Görgülü) the Federal Constitutional Court of Germany expressed the proposition that the practice cases of the European Court of Human Rights "should be considered" in legal proceedings of Germany. At the same time the Federal Constitutional Court stressed the importance of state sovereignty and pointed to the supremacy of the Basic Law of the Federal Republic of Germany, noting that while judging a case German courts must be guided, first and foremost, by the country's Basic law, and any violation of rights and freedoms of man and citizen must be judged, basing on the provisions of this document ${ }^{9}$. In other words, practice cases of the European Court of Human Rights are important for the authorities of the Federal Republic of Germany as long as they do not disagree with the provisions of the Basic law of the Federal Republic of Germany. It is noted that the German state authorities must aim at integrating the judgments of the European Court of Human Rights as well as universally recognized principles and norms of international law into national law ${ }^{10}$. The decisions of the European Court of Human Rights are stated to be important for the Federal Constitutional Court of Germany, for example, in cases of interpretation of the provisions of the Basic law, reasoning of its judgments and other similar cases (Kirchhof, 2011: 3682).

It should be noted that despite the stated proposition of the priority of "national sovereignty" the judgment of the Federal Constitutional Court of Germany on the Gorgulu's case was taken in complete compliance with the practice cases of the European Court of Human Rights ${ }^{11}$.

Regarding the Court of the European Union, it is noted in the constitutional law of Germany that this Court is not a "cassational instance" to appeal against the judgments of the national courts of the Federal Republic of Germany. The scope of this court is limited by the Memorandum of Association and regulatory acts of the European Union. In the field of human rights the Court of the European Union primarily considers violations of rights by the bodies of the European Union as well as violations of the provisions of the European Charter of Fundamental Rights by various normative legal acts of a participant-state of the European Union (Limbach, 2001: 2913). 
The judgment of the Court of the European Union dated 11.01.2000 and issued at the request of Tanja Kreil, a German citizen defending the women's right to serve in the Federal army, can serve an example of such a situation ${ }^{12}$. Initially, in 1998, the applicant appealed to the Hanover administrative court which rejected her complaint by making reference to the provisions of the Basic Law of the Federal Republic of Germany. According to these provisions this right was granted only to men at the age over 18. The Court of the European Union pointed out to the contradiction between the norm stated and the provisions of the European Union on the equality between men and women ${ }^{13}$. This resulted in corresponding amendments in Clause 2 of part 4 of Article 12 of the Basic Law of the Federal Republic of Germany. Then, in January 2001 the first 244 women enlisted in Bundeswehr. As per the data of January 2010, the number of women liable for military service in the Federal Republic of Germany amounted to 16900 employees, that made $8.96 \%$ of the total number of people enlisted in the army, of which 2600 women were among the officer personnel (S. Lopez). Thus, the appeal against the violation of the provisions of the European Charter of Fundamental Rights in the Court of the European Union made it possible for the women of the Federal Republic of Germany to defend their right to serve in the army with weapons in hand.

It should be noted that the proposition of the "dialogue" between multi-level courts formulated by the Federal Constitutional Court of Germany and the Constitutional Court of the
Russian Federation positively defends the state sovereignty. However, there is a downside of this. Any waiver of enforcement of the judgments of the European Court of Human Rights, first of all, restricts the right of a human to restore his/her violated rights or freedoms. The mentioned path opens up the possibilities for "politicization of the judgments" (Anichkin et al., 2012: 27), "juggling” with the rights and freedoms of man and citizen while taking specific situations in the state into account. In the end, it questions the necessity of the existence of both the Convention for the Protection of Human Rights and Fundamental Freedoms and the European Court of Human Rights.

It is only a strict observance of the propositions formulated by the Federal Constitutional Court of Germany and the Constitutional Court of the Russian Federation (appeal to the "right of exception" only in exceptional cases and with strict adherence to the Basic Law of the Federal Republic of Germany and the Constitution of the Russian Federation, respectively) that can favour the reduction of negative factors. At the same time, the "dialogue" of courts of different levels minimizes conventional-constitutional conflicts without impairment of the state sovereignty. The European Convention is intended to establish a minimum standard in the protection of human rights and fundamental freedoms, preserving a nation's identity, respecting a state's cultural, national and ethnic peculiar features, without trying to "wipe out any and all differences between national legal systems" (Luk'iantsev, 2000: 16)

\footnotetext{
O ratifikatsii Konventsii o zashchite prav cheloveka i osnovnykh svobod i Protokolov k nei: Feder. zakon ot 30 marta 1998 g. No. 54-FZ [On Ratification of the Convention on the Protection of Human Rights and Fundamental Freedoms and the Protocols Thereto: Federal Law No. 54-FZ dated March 30, 1998] (1998), In Sobranie zakonodatel'stva of the Russian Federation [Collected Legislation of the Russian Federation], 14, 1514.

2 On the citizen K.M. Tishchenko's complaint about violation of his constitutional rights by the provisions of part 1 of Article 1 of the Federal law of the Russian Federation "On Compensation for Violation of the Right to the Legal Procedure within a Reasonable Time or the Right to the Execution of a Judicial Act within a Reasonable Time": The Definition of the Constitutional Court of the Russian Federation No. 1258 dated June 28, 2012 [Electronic resource], In Legal reference system "ConsultantPlus".
} 
3 O primenenii sudami obshchei iurisdiktsii Konventsii o zashchite prav cheloveka i osnovnykh svobod ot 4 noiabria 1950 goda i Protokolov k nei: Postanovlenie Plenuma Verkhovnogo Suda RF ot 27 iiunia 2013 g. № 21 [On Application of the Convention for the Protection of Human Rights and Fundamental Freedoms dated November 4, 1950 and the Protocols Thereto by the Courts of General Jurisdiction: the Resolution of the Plenum of the Supreme Court of the Russian Federation No. 21 dated June 27, 2013]. (2013). In Russkaia Gazeta [Russian Newspaper], 145.

4 Konstantin Markin protiv Rossii: Reshenie Evropeiskogo Suda po pravam cheloveka ot 7 oktiabria 2010 g. ((№ 30078/06) [Konstantin Markin vs. Russia: the Judgment of the European Court of Human Rights Dated October 7, 2010 (No. 30078/06)], In Ofitsial'naia baza dannykh Evropeiskogo Suda po pravam cheloveka "HUDOC" [The Official Database of the European Court of Human Rights "HUDOC"]. Available at: http://www.hudoc.echr.coe.int

5 Anchugov i Gladkov protiv Rossii: Reshenie Evropeiskogo Suda po pravam cheloveka ot 4 iiulia 2013 g. ((№ 11157/04 and 15162/05) [Anchugov and Gladkov vs. Russia: the Judgment of the European Court of Human Rights Dated July 4, 2013 (No. 11157/04 and 15162/05)], In Ofitsial'naia baza dannykh Evropeiskogo Suda po pravam cheloveka "HUDOC" [The Official Database of the European Court of Human Rights "HUDOC"]. Available at: http://www.hudoc.echr.coe.int

6 Re. to the scrutiny of constitutionality of the provisions of Article 1 of the Federal law "On Ratification of the Convention on the Protection of Human Rights and Fundamental Freedoms and the Protocols thereto", Clauses 1 and 2 of Article 32 of the Federal law "On International Treaties of the Russian Federation", Parts 1 and 4 of Article 11, Clause 4 of Part 4 of Article 392 of the Code of Civil Procedure of the Russian Federation, Parts 1 and 4 of Article 13, Clause 4 of part 3 of Article 311 of the Code of Arbitration Procedure of the Russian Federation, parts 1 and 4 of Article 15, Clause 4 of part 1 of Article 350 of the Code of Administrative Procedure of the Russian Federation and Clause 2 of part 4 of Article 413 of the Code of Criminal Procedure of the Russian Federation in connection with the inquiry of a group of deputies of the State Duma: Judgment of the Constitutional Court of the Russian Federation No. 21-P dated August 14, 2015. Available at the official Internet portal of legal information: http://www.pravo.gov.ru. 17.07.2015.

7 Re. to the check of constitutionality of the provisions of Article 1 of the Federal law "On Ratification of the Convention on the Protection of Human Rights and Fundamental Freedoms and the Protocols thereto", Clauses 1 and 2 of Article 32 of the Federal law "On International Treaties of the Russian Federation", parts 1 and 4 of Article 11, Clause 4 of part 4 of Article 392 of the Code of Civil Procedure of the Russian Federation, parts 1 and 4 of Article 13, Clause 4 of part 3 of Article 311 of the Code of Arbitration Procedure of the Russian Federation, parts 1 and 4 of Article 15, Clause 4 of part 1 of Article 350 of the Code of Administrative Procedure of the Russian Federation and Clause 2 of part 4 of Article 413 of the Code of Criminal Procedure of the Russian Federation in connection with the inquiry of a group of deputies of the State Duma: Judgment of the Constitutional Court of the Russian Federation No. 21-P dated July 14, 2015. Available at the official Internet portal of legal information: http://www.pravo.gov.ru. 17.07.2015.

Ibid.

9 Beschluß des Zweiten Senats vom 14. Oktober 2004. 2 BvR 1481/04 [Online-Durchsuchungen]. (2004). In Entscheidungen des Bundesverfassungsgerichts. Available at: http://www.servat.unibe.ch/dfr/bv111307.html.

10 Ibid.

11 Ibid.

12 EUR-Lex: Urteil des Europäischen Gerichtshofes vom 11.01.2000. C-285/98, available at: http:eur-lex.europa.eu.

13 EG-Richtlinie 79/7/EWG des Rates vom 19.12.1978 zur schrittweisen Verwirklichung des Grundsatzes der Gleichbehandlung von Männern und Frauen im Bereich der sozialen Sicherheit, available at: http:eur-lex.europa.eu.

\section{References}

Anichkin, A.S., Avak'ian, A.S., Agapov, D.S. (2012). Rol' politicheskogo protsessa v razvitii Konstitutsii Rossiiskoi Federatsii [The Role of the Political Process in the Development of the Constitution of the Russian Federation], In Sbornik materialov mezhdunarodnoi nauchnoi konferentsii iuridicheskogo fakul'teta MGU imeni M.V. Lomonosova [The Materials of the International Scientific Conference of the Faculty of Law of Moscow State University named after M.V. Lomonosov], Moscow, 27-33.

Burkov, A.L. (2006). Primenenie Evropeiskoi konventsii o zashchite prav cheloveka v sudakh Rossii [Application of the European Convention on Human Rights in Russian Courts]. Ekaterinburg, 264 p.

Churkina, L.M. (2005). Obiazatel'stva gosudarstv-uchastnikov Evropeiskoi konventsii o zashchite prav cheloveka i osnovhikh svobod po ispolneniiu postanovlenii Evropeiskogo suda [Obligations of the Participating Member States of the European Convention for the Protection of Human Rights and Fundamental Freedoms to Enforce the Judgements of the European Court]. Ekaterinburg, 134 p.

Kirchhof, F. (2011). Protection of fundamental rights by european and national courts [Grundrechtsschutz durch europäische und nationale Gerichte], In NJW, 51, 3681-3686.

Kozhevnikov, O.A. (2010). Pozitsii Evropeiskogo Suda po pravam cheloveka i sudebnaia reforma v Rossii [The Propositions of the European Court of Human Rights and Judicial Reform in 
Russia], In Zakony Rossii: Opyt, Analiz, Praktika [Laws of Russia: Experience, Analysis, Practice], (9), 62-68.

Laptev, P.A. (2003). Rossiiskoe pravosudie i evropeiskii sud po pravam cheloveka [Russian Justice and the European Court of Human Rights], In Prava Cheloveka v Rossii i Pravozashchitnaia Deiatelnost' Gosudarstva [Human Rights in Russia and Legal activity of the State], (3), 24-31.

Limbach, J. (2001). Das Bundesverfassungsgericht und der Grundrechtsschutz in Europa [The Federal Constitutional Court and the Protection of Fundamental Rights in Europe], In NJW, 40, 29132917.

Lopez, S. Normalität: Frauen in der Bundeswehr, available at: http://www.bundeswehr.de/ portal/a/bwde/streitkraefte/grundlagen/frauen_in_der_bw?yw_contentURL=/C1256EF4002AED30/ W27DXCZE807INFODE/content.jsp.

Luk'iantsev, G.E. (2000). Evropeiskie standarty v oblasti prav cheloveka: teotiya i praktika funktsionirovaniia Evropeiskoi konventsii o zashchite prav cheloveka i osnovnikh svobod [European Standards in the Field of Human Rights: Theory and Practice of the European Convention for the Protection of Human Rights and Fundamental Freedoms]. Moscow, $280 \mathrm{p}$.

Prikhod'ko, T.V. (2012). K voprosu o mezhdunarodnykh istochnikakh standartov prav cheloveka, primeniaemykh v Rossiiskoi Federatsii [On the Issue of International Sources of Standards of Human Rights in the Russian Federation], In Nauka XXI veka: novii podkhod [Science of XXI Century: New Approach], (4), 111-117.

Prikhod'ko, T.V. (2013). Istochniki standartov prav i svobod RF i FRG: sravnitel'no-pravovoi analiz [Sources of Standards of Rights and Freedoms in the Russian Federation and the Federal Republic of Germany: comparative legal analysis], In Aktual'nye problemy rossiiskogo prava [Actual Problems of Russian Law], (6), 660-665.

Tiunov, O.I. (2012). Rol' mezhdunarodno-pravovykh standartov v regulirovanii vzaimodeistviia mezhdunarodnogo i natsional'nogo prava [The Role of International Legal Standards in Regulating Interaction between International and National Law], In Zhurnal rossiiskogog prava [Journal of Russian Law], (12), 72-73.

Zor'kin, V.D. (2004). Pretsedentnyi kharakter reshenii Konstitutsionnogo Suda Rossiiskoi Federatsii [The Precedent Character of the Decisions of the Constitutional Court of the Russian Federation], In Zhurnal rossiiskogo prava [Journal of Russian Law], (12), 3-9. 


\section{Решения Европейского Суда по правам человека \\ как источники стандартов в области прав \\ и свобод человека и гражданина \\ в Российской Федерации}

Т.В. Приходько

Байкальский государственный университет Россия, 664003, Иркутск, ул. Ленина, 11

В статье проводится анализ юридической сильр решений Европейского Суда по правам человека в контексте правовой позищии Конституционного Суда Российской Федерации, сформулированной в Постановлении от 14 июля 2015 г. № 21-П. При использовании сравнительноправового метода исследования изучается опыт взаимодействия Федеративной Республики Германии с Европейским Судом по правам человека, а также судом Европейского Союза. Делается вывод о положительных и отрицательных последствиях «отступления» государства от исполнения решений Европейского Суда по правам человека.

Ключевые слова: права человека, свободы, юридическая сила, суверенитет, право на возражение, диалог судов, Конституция Российской Федерации, Европейская конвениия о зашите прав человека и основных свобод, Европейский суд по правам человека, Конституционный Суд Российской Федерачии, Постановление Конституционного Суда РФ от 14 июля 2015 г. № 21-П, Федеративная Республика Германия, Основной закон Федеративной Республики Германии, Суд Европейского Союза, Федеральный Конституционный суд Германии.

Научная специальность: 12.00.00 - юридические науки. 